Beliefs about Causes of Wealth and Poverty: A Field Study in the United Arab Emirates 



\section{Beliefs about Causes of Wealth and Poverty: A Field Study in the United Arab Emirates}

Husein M. Al-Othman*

Mohammad A. Alhourani *

$$
\text { ملخص الدراسة }
$$

تهدف الدراسة إلى التعرف على معتقدات الطلبة الجامعيين حول أسباب الغنى والفقر في المجتمع الإماراتي، والعلاقة الارتباطية ما بين الخصانص الاجتماعية والديموجرافية للطلبة ومعتقداتهم نحو أسباب الغنى والفقر. اعتمدت الدراسة على منهج المسح الاجتماعي وتم جمع البيانات من خحلال استمارة الاستبيان وجماعات النقاش البؤرية،

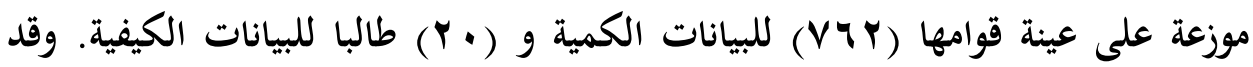
توصلت الدراسة لعدد من النتائج أهمها: أن المبحوثين يعتقدون بأهمية العوامل المجتمعية والبنائية بالدرجة الأولى، يليها العوامل الفردية، والعوامل القدرية كمسببات للفنى والفقر. كما كشف التحليل عن وجود ارتباط ذي دلالة إحصائية بين متغير المنطقة وتفسيرات المبحوثين الفردية والبنائية للغنى. بالإضافة إلى الارتباط بين النوع الاجتماعي وتفسيرات المبحوثين الفردية والبنائية للفقر. كما كشفت نتائج الدراسة عن وجود ارتباط إيجابي وسلبي بين المكانة الاجتماعية (الطبقة الذاتية ودخل الأسرة) من جهة، والتفسيرات الفردية والبنائية للفقر (على التوالي) من جهة أخرى.

الكلمات المفتاحية: الغنى، الفقر، المعتقدات، اللامساواة الاجتماعية.

\footnotetext{
* Acting Dean of College of Arts, Humanities, and Social Sciences, University of Sharjah,

* Sociology Department, University of Sharjah,
} 


\section{Introduction}

Sociologists study individuals' beliefs about wealth and poverty under the wider sociological concept of social inequality, which is regarded as a social phenomenon that refers to people's statuses, roles and their attitudes, values, beliefs, social classes and their differentiation in scarce resources such as wealth, education, occupation and power.

From the perspective of social justice research, the significance of beliefs about the causes of poverty and wealth lies in that they reveal whether people consider the outcomes of the rules of the game in a society to be fair. In this they represent beliefs in the actual or existential justice of the social order. If the outcomes are unfair, then it seems reasonable to suppose that individuals would support measures to intervene in the distribution. Central to the idea of justice is the premise that in every society people creates an implicit "social contract," of which principles of distributive justice are a part. Thus we can expect that attributions behind the causes of poverty and wealth are influenced by the perceived income distribution in the society, views on the fairness of the distributive system, and by the individual's position in the system of inequalities and its changes since the start of reforms in particular.

Furthermore, the beliefs about poverty and wealth are particularly crucial in the developing world, because popular perceptions of social inequality in said societies affect policy prescriptions tailored to address these inequalities. It also apprises the level of engagement at the individual and societal levels taken to address social inequality.

A lot has been written about beliefs of poverty and wealth in advanced Western societies. However, little research has been done on social inequality and stratification especially in regards to beliefs 
and attitudes of people toward the causes of poverty in Arab societies (Alothman, 2005; Nasser et al., 2002; Abouchedid and Nasser, 2001). At the same time, no research has studied beliefs about wealth in Arab societies. Inequality in the Arab society has become a critical issue following the aftermath of a pro-democracy upheaval which has been sweeping the region since 2011 in Tunisia, Libya, Egypt, Yemen, Syria, and Jordan. The extensive protests led by Arab youths have challenged Arab authoritarian political regimes under slogans calling for social justice, integrity and freedom. As many researchers have argued, the major causes of Arab uprising against authoritarian regimes is attributed to a deep sense of inequality among social groups in the Arab societies over the last four decades (Moghadam, 2013; Salih, 2013).

U.A.E. classified as one of the very high human development countries with a .827 value of Human Development Index and a gross national income per capita of \$58,068 in 2013 (UNDP, 2014: 160). The majority of Emirati citizens lives within a relatively high well-being and receive free health care, education, water, electricity, and welfare protection of vulnerable groups. Nonetheless, the country's wealth remains unevenly distributed among Emirati themselves, and between them and the expatriates where Emirati citizens enjoy preferential treatment to expatriates. For instance, the available statistics indicate that the Gini index of income distribution in the UAE society has reached 38.30\% (Arab League, 2013: 337). More so, $10.8 \%$ of national households earn an annual income accounting to less than 120000 dirhams, whereas $16.5 \%$ of national households earn annual incomes between 120000 to less than 240000 dirhams while the remaining households earn more than 240000 dirhams (National Bureau of Statistics, 2009: 225). In contrast, only $35.6 \%$ of national and non-national households earn 
annual incomes higher than 240000 Dirham (National Bureau of Statistics, 2009: 235).

The research problem statement revolves around seeking answers for the following research questions: How do university students in U.A.E. explain causes of wealth and poverty? What are the correlations between the socio-demographic characteristics of the research respondents and their beliefs about wealth and poverty in U.A.E.?

\section{Theoretical Background}

In this article we follow a social constructivist perspective, according to which perceived social reality forms a basis for the explanations people offer and policies they endorse (Kluegel and smith 1986; Wegner, 1987). According to this perspective, beliefs in the causes of wealth and poverty are determined to a large extent by individuals' perceptions of the justice of the current economic system. For example, those who believe that the economic system is operating in a just manner, rewarding effort and bringing basic welfare, would be more likely to attribute poverty to the shortcomings of individuals than to the flaws of the economic system (Stephenson, 2000).

Hence, this perspective is connected with the notion of legitimacy and attempts to explain the mechanism of legitimization of inequalities through the process of attribution. When people think that the social order is legitimate, they will tend to attribute poverty and wealth to individual factors. Those who consider the existing order as illegitimate tend to attribute wealth and poverty to inequalities in the structure of opportunity or lack of jobs.

As sociologists argue, inequalities are patterned and structured in most human societies based on people's position in the economic system (social class) and ascribed statuses (gender and race). This 
might determine one's life opportunities related to income, assets and other material resources, as well as access to political power, prestige and lifestyle (Rothman, 2004). Also, in many countries, top income shares are disproportionally high and often rising; and the top $1 \%$ or $2 \%$ usually earn as much as the bottom $50 \%$ of the population combined (Medeiros and Ferreira de Souza, 2015). More so, the dominant ideology of stratification involves sociocultural arrangements of values, beliefs, laws and norms, while social institutions legitimize and institutionalize inequality schemes in most human societies (Rothman, 2004). On the other hand, Kluegel and Smith (1986) argue that there are three factors that affect beliefs about inequality in American society; the first factor is the dominant ideology which emphasizes equal opportunities, individualistic success, and personal responsibility of individuals in facing their fate. The second factor is people's position in the inequality system which involves different experiences and self-interest (race, gender, age, education etc.) The third factor is "social liberalism," especially toward issues such as poverty, race, relations, and women's participation in public life. Moreover, beliefs regarding the causes of wealth and poverty are shaped by the perceptions of people to the justice system of the current social order (Stephenson, 2000).

According to Kluegel and Smith (1986) and Smith and Stone (1989), individualism, culturalism, structuralism, and fatalism are four models of competing meta-theories about causes of wealth and poverty. The individualistic and cultural explanation models of wealth and poverty focus on micro factors of personality traits. For instance, wealth is attributed to hard work, thrift, ability, effort, drives, and motives whereas poverty is attributed to opposite traits such as being lazy, lack of thrift and effort, as well as loose morals and consumption of drugs. Furthermore, the structural explanation model of wealth and poverty emphasizes the importance of macro 
and societal factors such as equal opportunities for wealth; and lack of opportunities, discrimination, lack of education, low wages and long term of unemployment for poverty. Meanwhile, the fatalistic explanation model attributes wealth and poverty to factors beyond individuals' control such as good luck and fortune for wealth, and bad luck and illness for poverty.

\section{Literature Review}

Most research on beliefs and attitudes about inequality has been conducted on causes of poverty in the United States (Feagin, 1975; Kluegel and Smith, 1986; Hunt, 1996, 2002; Cozzarelli, et al., 2001; Robinson, 2009), Turkey (Morcol, 1997), Jordan (Alothman, 2005), Lebanon, South Africa, and Portugal (Nasser et al., 2002), Lebanon (Abouchedid and Nasser, 2001), Britain (Furnham, 1982), Australia and United States (Feather, 1974), Finland (Niemela, 2008), Hong Kong (Sheck and Man-SzeMa, 2008; Sheck, 2003), and Canada, Manila, and Philippines (Hine and Montiel, 1999). In contrast, little research has been done on beliefs and attitudes about causes of both wealth and poverty in United States (Smith, 1985; Smith and Stone, 1989; Hunt, 2004) Russia and Estonia (Stephenson, 2000), Russia (Gorshkov and Tikhonova, 2006), United States, Germany, the Netherlands, Hungary and Post-Communist countries (the Czech Republic and Russia) (Kreidle, 2000). Ghana (Asiedu, Dzukoto, Wallace, Mensah, 2013)

Most research supports the individualistic perception in answering the question of why the poor are poor (Feagin, 1975; Huber and Form, 1973; Kluegel and Smith, 1986; Hunt, 1996; Smith and Stone, 1989; Hunt, 2004). Also, in a comparative study between Australians and Americans, the empirical analysis revealed that Australians embrace the individualistic explanation of poverty, but their counterparts were found to be more likely than them to attribute the causes of poverty to the characteristics of the poor 
(Feather, 1974). On the other hand, some studies in Finland (Niemela, 2008), Jordan (Alothman, 2005 ;Shahateet, 2007) Turkey (Morcol, 1997), and Lebanon (Abouchedid and Nasser, 2001) Saudi Arabia (Al Kahtani, 2004) Egypt (Mervat, 2016; El laithy,1997 ) Algeria (Hadj, 2014) Palestine (Hasan, 2005) explain poverty in terms of structural forces. In a comparative study, South Africans were found to be more individualistic in their attribution to the causes of poverty than Portuguese and Lebanese (Nasser et al., 2002). Contrary to prior evidence from Anglo-Saxon countries, social blame prevailed as the most popular explanation of poverty in nearly all of the twenty countries studied (Oorschot and Halman, 2000). That is, the majority of people living in industrialized welfare states believe that poverty is the outcome of actions rather than the inevitable result of individual or social fate. In contrast to the popularity of individualistic and structural explanations about causes of poverty, fatalistic beliefs were found to be least popular in United States (Hunt, 2004; Feagin, 1975), Jordan (Alothman, 2005), Turkey (Morcol, 1997), Lebanon (Abouchedid and Nasser, 2001), and Finland (Niemela, 2008). On the other hand, Hunt (2004) and Smith and Stone (1989) found that Americans mostly support the individualistic explanations of wealth.

The empirical literature regarding factors affecting beliefs about wealth and poverty are documented in some developed and developing countries. For instance, research has revealed inconsistent results of gender differences in explaining beliefs and attitudes about poverty and wealth in different countries. Women in U.S.A. were found to be more likely than men to support structural explanations of poverty (Kluegel and Smith, 1986; Hunt, 1996) whereas other studies indicate that men were found to be stronger believers in structural explanations of poverty (Morcol, 1997). However, Cozzarelli et al., (2001) found gender to be a silent 
variable in determining beliefs about poverty. Also, research in United States has uncovered a contradictory association between social class and beliefs regarding causes of poverty. For instance, Hunt (1996) found that lower classes are more likely to support structural explanations than individualistic ones in explaining poverty, whereas the middle or higher classes are linked to attribute poverty to individualistic explanations. Also, income level as an indicator of social class is positively associated with individualistic explanations of poverty (Smith, 1985). However, some studies in United States and Turkey found that individualistic explanations for causes of poverty are not common among individuals with average income (Feagin 1972; Morcol, 1997). In Turkey, income and education levels were found to be negatively associated with fatalistic explanations of poverty (Morcol, 1997). Other research in United States and Britain revealed that individuals with intermediate level of education tend to favor the individualistic explanation of poverty whereas people who hold a low or higher level of education tend to support structural explanation of poverty (Feagin, 1972; Furnham, 1982).

In addition, some research found differences among age groups. In other words, younger individuals tend to support structural explanations as causes of poverty, whereas elders tend to support individualistic ones (Feagin, 1972; Feather, 1974; Hunt, 1996; Morcol, 1997). Conclusively, little research has been conducted to identify the effect of religion or religiosity on beliefs about poverty. Hunt (2002) found that Protestants and Catholics tend to support individualistic explanations of poverty, while Jews are more likely to support structuralist beliefs. Moreover, Jews and Catholics held the strongest presence in the spectrum of fatalistic explanations of poverty (Hunt, 2002). 


\section{Measures and Sampling Procedures Dependent Variables}

The dependent variables in this study (beliefs about causes of wealth and poverty) were measured by using Smith and Stone (1989) scales after testing the validity and the reliability of its items. The question wording is as follows: "During the past four decades, U.A.E. has been witnessing tremendous changes in socio-economic development and has become a welfare state. As you know, there are different causes behind wealth and poverty; we are going to name some of these causes and we would like you to rate their importance as causes of wealth to people who retain the highest $20 \%$ of income in the country; and their importance as causes of poverty to those people whose income falls in the lower $20 \%$ based on 3 scales: (3. Very important, 2. Somewhat important and 1. Not important at all).

\section{Research participants}

For quantitative data, questionnaires were distributed to every student enrolled in the Emirati Society sections (students enrolled in these sections come from all colleges at the university) for Fall 2014-2015 term during the period 15 - 22 of September, 2014 at the University of Sharjah. The total number of the students was 795 . The number of completed questionnaires was 762 , with a response rate of $95.8 \%$. For qualitative data, two focus groups were formulated. The first one was a male focus group consisting of 5 graduate and 5 undergraduate students, while the second was a female focus group consisting of 5 graduate and 5 undergraduate students. The meetings were scheduled during the period of October13-16, 2014, for the male and female groups. The quantitative data is imperative for the current study in order to integrate objective and subjective responses, and to display how people construct their own beliefs about the causes of poverty and 
wealth. In summary, the socio-demographic characteristics of the research participants are shown below in table (1).

Table (1) Distribution of Respondents by Soci-Demographic Characteristics $(\mathrm{N}=762)$.

\begin{tabular}{|c|c|c|c|}
\hline \multicolumn{2}{|c|}{ Variables } & Frequency & $\%$ \\
\hline \multirow{3}{*}{ Sex } & Male & 172 & 22.6 \\
\hline & Female & 590 & 77.4 \\
\hline & Total & 762 & 100 \\
\hline \multirow{3}{*}{ Region } & Region 1 & 681 & 89.4 \\
\hline & Region 2 & 81 & 10.6 \\
\hline & Total & 76 & 100 \\
\hline \multirow{6}{*}{ Age } & Less than 19 & 167 & 21.9 \\
\hline & $19-20$ & 292 & 38.3 \\
\hline & $21-22$ & 174 & 22.8 \\
\hline & $23-24$ & 45 & 5.9 \\
\hline & $25+$ & 84 & 11.0 \\
\hline & Total & 762 & 100 \\
\hline \multirow{3}{*}{ Marital Status } & Married & 121 & 15.9 \\
\hline & Non-Married & 641 & 84.1 \\
\hline & Total & 762 & 100 \\
\hline \multirow{4}{*}{ Subjective Class } & High class & 67 & 8.8 \\
\hline & Middle class & 691 & 96.7 \\
\hline & Lower class & 4 & 5 \\
\hline & Total & 762 & 100 \\
\hline \multirow{3}{*}{ Working Status } & Working & 130 & 17.1 \\
\hline & Not Working & 632 & 82.9 \\
\hline & Total & 762 & 100 \\
\hline \multirow{3}{*}{ Student Type } & Bachelor & 696 & 91.3 \\
\hline & Graduate & 66 & 8.7 \\
\hline & Total & 762 & 100 \\
\hline \multirow{6}{*}{ Family Income } & Less than 10000 & 94 & 12.3 \\
\hline & $10001-20000$ & 208 & 27.3 \\
\hline & $20001-30000$ & 234 & 30.7 \\
\hline & $30001-40000$ & 77 & 10.1 \\
\hline & $40001-50000$ & 57 & 7.5 \\
\hline & More than 50000 & 92 & 12.1 \\
\hline
\end{tabular}




\begin{tabular}{|c|c|c|c|}
\hline & Total & 762 & 100 \\
\hline \multirow{3}{*}{$\begin{array}{c}\text { Religiosity } \\
\text { (Prayers) }\end{array}$} & Always & 596 & 78.2 \\
\cline { 2 - 4 } & Sometimes & 157 & 20.6 \\
\cline { 2 - 4 } & I don't pray & 9 & 1.2 \\
\cline { 2 - 4 } & Total & 762 & 100 \\
\hline \multirow{3}{*}{ Nationality } & Emirati & 409 & 53.7 \\
\cline { 2 - 4 } & Non- Emirati & 353 & 46.3 \\
\cline { 2 - 4 } & Total & 762 & 100 \\
\hline
\end{tabular}

\section{Validity and reliability}

The items of Smith and Stone scales (1989) about causes of wealth and poverty were reviewed by five professors from the Sociology department in the University of Sharjah to assess the validity of these scales in UAE society. Some items were replaced or deleted from the scales.

Exploratory factor analysis was applied on beliefs items related to causes of wealth and poverty (38 explanation items). The 32 explanation items were loaded up on three factors of causes of wealth and three factors of causes of poverty (see table 1). Consequently, variables were selected for each index which had factor loadings higher than .5 (see table 2). Therefore, three indexes of wealth and three indexes of poverty were constructed by using syntax commands in SPSS. For more details see table (2). 
Table (2) Exploratory factor analysis for wealth and poverty scales $(\mathbf{N}=762)$

\begin{tabular}{|c|c|c|}
\hline Factor & Item & Loading \\
\hline \multirow{6}{*}{$\begin{array}{l}\text { Wealth Individualistic List } \\
\text { of Items }\end{array}$} & Possess drive and perseverance & .623 \\
\hline & Are willing to take risks & .717 \\
\hline & Are hard working & .531 \\
\hline & Are thrifty & .543 \\
\hline & Live in strong families & .730 \\
\hline & Have high moral standards & .534 \\
\hline Average & & .613 \\
\hline \multirow{7}{*}{ Wealth Structuralist Items } & Have contact and pull & .563 \\
\hline & Have good education & .761 \\
\hline & Receive large inheritances & .644 \\
\hline & Receive favoritism in hiring & .693 \\
\hline & Are shown favoritism in promotion and & .681 \\
\hline & wages & .584 \\
\hline & $\begin{array}{l}\text { Receive special treatment from } \\
\text { government }\end{array}$ & \\
\hline Average & & .651 \\
\hline \multirow{3}{*}{ Wealth Fatalistic Items } & Good Luck & .531 \\
\hline & Higher intelligence & .593 \\
\hline & Are born in well-known tribes & .622 \\
\hline Average & & .582 \\
\hline \multirow{6}{*}{$\begin{array}{l}\text { Poverty Individualistic } \\
\text { Items }\end{array}$} & Are not thrifty & .512 \\
\hline & Lack drive and perseverance & .623 \\
\hline & Abuse drugs and alcohol & .522 \\
\hline & Are unwilling to take risks & .602 \\
\hline & Are lazy & .623 \\
\hline & Lack suitable financial administration & .653 \\
\hline Average & & .589 \\
\hline \multirow{7}{*}{ Poverty Structuralist Items } & Lack suitable employment opportunities & .589 \\
\hline & Low wages in some occupations & .528 \\
\hline & Study in public school & .571 \\
\hline & Do not have "contacts" or "pull" & .731 \\
\hline & Low level of education & .611 \\
\hline & Dependency on government assistance & .555 \\
\hline & Lack of justice in society & .728 \\
\hline Average & & .616 \\
\hline \multirow{4}{*}{ Poverty Fatalistic Items } & Bad luck & .600 \\
\hline & Chronic diseases and disabilities & .638 \\
\hline & Lack the talent to succeed & .568 \\
\hline & Low intelligence & .598 \\
\hline Average & & .601 \\
\hline
\end{tabular}


Also, alpha Chronbach's values were counted to check the internal consistency reliability for the poverty and wealth explanation items. According to table (3), the highest value of alpha Chronbach (.85) was for the items of Wealth Structuralistic Index whereas the lowest value (.79) was for the items of Poverty Fatalistic Index. Consequently, these values are regarded high values and accepted to build the six scales for the poverty and wealth explanation items.

Table (3) Alpha Chronbach's Values of the Wealth and Poverty Indexes

\begin{tabular}{|c|c|c|}
\hline No. & Wealth and Poverty Indexes & alpha Chronbach's values \\
\hline 1 & Wealth Individualistic Index & .84 \\
\hline 2 & Wealth Structuralistic Index & .85 \\
\hline 3 & Wealth Fatalistic Index & 80 \\
\hline 4 & Poverty Individualistic Index & .83 \\
\hline 5 & Poverty Strucutralistic Index & .79 \\
\hline 6 & Poverty Fatalistic Index & \\
\hline
\end{tabular}

\section{Analysis and Discussion}

Quantitative (means, standard deviations, and Pearson correlation coefficients $\mathrm{r}$ ) and qualitative (focus group discussions) analysis were used to answer the question of whether university students in U.A.E. blame individuals, society or fate in their beliefs to explain causes of wealth and poverty. According to table 4, structuralism and individualism guide the respondents' beliefs toward causes of wealth and poverty in U.A.E. The mean score of the structural explanation of wealth scale is recorded the highest mean (2.561) compared to the individualistic (2.208) and fatalistic (1.870) scales out of 3 points. For instance, having contact and pull is regarded the most important example of societal factors behind being a wealthy person, followed by receiving good education, favoritism in hiring, favoritism in wages and promotion, inheritance, and receiving special treatment from government. For individualistic explanations of wealth, hard-working is recorded as the highest item of beliefs toward causes of wealth, followed by possessing drive and 
perseverance, living in strong families, high moral values, being thrifty, and taking risks. Least popular are the fatalistic explanations which attribute wealth to good luck, being from well-known tribes, and high intelligence, according to their importance.

On the other hand, the results of qualitative analysis from the focus groups reinforce the findings of the social survey in regards to structuralist factors leading beliefs on causes of wealth. Students refer to the emergence of rich families in the UAE as a new phenomenon that materialized during the twenty-first century as a result of the country's oil boom. Out of the 20 participants, 9 stressed the importance of structuralist factors, versus 7 participants who weighed individualistic factors heavier as causes of wealth in UAE society. The remaining (4) believe that fate determines wealth or poverty. Participants who emphasized structuralist factors noted that the relationship with the country's rulers and those in power, kinship ties with them, as well as receiving education in the country's early years of inception formed a rare opportunity to amass wealth. In other words, this group of participants believes that a strong network of influential people in the State offers an opportunity to build a fortune through being appointed a high salary job, receiving preferential promotions, or through partnerships in trade with these influencers. People of power or those associated with them enjoy rapid wealth due to oil revenues or partnership revenue when establishing international companies that require the citizen to be a shareholder of at least $51 \%$ of the capital. More so, the rulers of the seven emirates distribute residential, commercial, industrial and agricultural land to many of the citizens. Many citizens end up selling this land cheaply, some invest, while others sell it after price-increments.

Additionally, some participants believe that the structural factors make all the difference in determining their future and wealth. For example, a graduate male participant (35 years old) shared: 
"working as a police officer enables me to sponsor 40 Pakistani tailors annually, for a 10000-dirham fee each." Another participant (19 years) adds: "my father's relationship with powerful people allowed me access to high-end jobs that allowed me to generate imaginary figures in a short span of time." One female graduate student (33 years) adds: "My parent's strong relationship with some decision-makers helped me save time by getting quick promotions to a senior position in a semi-governmental institution." While a female med student (22 years) shares: "my father sent me to the best private school in the country and now I study Medicine. He has always assured me that a strong education is the gate to success in UAE. My father's own strong educational background and relationship with decision-makers assisted in him obtaining top positions in record times, thus allowing us to live among the upperclass.

On the other hand, participants who hold individualistic beliefs in the explanation of wealth argue that an individual is responsible for identifying their place in society through retaining qualities related to motivation and hard work, as well as displaying good manners; thus increasing the likelihood of success, entailed by wealth and distinction within their community. One participant shares his story (45 years): "My love for hard work and self-learning -an attribute I learned from my father- helped in achieving my goals without anyone's assistance. At a time when people were ashamed of certain jobs, I approached them and built my fortune with every drop of sweat I could despite my modest educational background. I relied on myself in completing my high school diploma, received a bachelor's degree, and now I'm pursuing my Masters. I don't need these degrees and will unlikely utilize them for my job, but they give my social standing a push." A 23-year old participant tells: "In my household, I was taught that discipline, commitment to religion, 
high morality, and sincere hard work are factors that lead to success and a privileged place in society. My father is a true example of this since it is his self-reliance and mentioned factors that allowed him to hold his position in society. I plan on following in his persevering footsteps by relying on myself to build my personal wealth."

Contrastingly, only a few participants link wealth with luck, and instead associate it with fate. To exemplify, one participant (30 years old) says: "Luck played a big role in forming my fortune. Although I'm young and its irrelevance to my actual job, an expatriate founded a cleaning service company that needed a partner, and so I was blessed with plenty of money from God." A female participant (20 years) adds: "There are many factors behind wealth, but among the most important ones is belonging to an important family. This automatically enables you to get a good education, position, or trade partnership. I'm lucky to belong to one of these families leaving me with huge future prospects."

As for causes of poverty, the mean scores for the structural explanation of poverty is regarded the highest mean (2.661) compared to individualistic (2.038) and fatalistic (1.521) scales; but the structural belief items of respondents toward poverty vary. Lack of social justice in society is recorded the highest mean of the structural items explaining poverty, followed by low level of education, lack of suitable employment opportunities, lack of contacts, dependency on government assistance, low wages in low prestige of occupations, and studying in public schools. On the other hand, the mean score of the individualistic explanation of poverty ranked second while focusing on the importance of traits such lack of suitable financial administration, unwillingness to take risks, alcohol and drug abuse, lack of drive, not being thrifty, and being lazy. Least popular is the fatalistic explanations of poverty among the respondents' beliefs. 
The focus group participants agree that there is no absolute or extreme poverty among citizens in the UAE, while this may exist among low-income expatriate families, especially those with basic education and work in cleaning services or unskilled labor jobs. Notably, they refer to relative poverty among citizens as an attribute of any social welfare community. Qualitative analysis supports the findings of the quantitative analysis regarding the beliefs of the causes of poverty. 10 participants indicate that a low level of education, lack of relations with those in power, retaining low-income jobs, and depending on government assistance are the reasons behind the poverty of citizens and non-citizens in UAE society. This indicates that the issue of poverty among this group of students is linked to societal and structural factors.

For example, one participant says ( 29 years): "Thank God we live a decent life, but I think my parents' low educational level contributed to lesser opportunities for greater wealth in a country where citizens and expats become rich because of their education or their relationship with influencers. The Government has helped us live without anyone's charity, but we live within the minimum compared to others who live in luxury." A female (25 years) participant adds: "We've lived here for 30 years, but the opportunities ahead of my father, brothers, and even me have been and will remain limited not because we are uneducated, but because we lack relations with influencers. My siblings and I are doing okay, but still not up to the level of our peers with similar educations, mostly because they have networks that we do not."

In return, 7 participants indicated the importance of individualistic characteristics that contribute to poverty and suffering: laziness and dependence on others, wastefulness, drug and alcohol addiction, and poor distribution of wealth. For example, one participant says (24 years old): "I believe that drug addiction is what destroys a family. 
My uncle who used to run his own private business brilliantly lost his fortune because of it, and now his family lives off government welfare." One participant (27 years) says: "Many people take on extravagant and wasteful behaviors when they can't afford it. In an attempt to keep up with the elite surrounding them, those whose incomes do not surpass 20000 dirhams are risking falling into poverty by buying luxury cars, demanding expensive wedding receptions, and traveling abroad to achieve a fake social status when their resources do not allow it." Another participant (21 years) adds: "Our social welfare has reinforced byproducts of laziness such as relying on servants and drivers; some of us fully depend on expats to do our jobs. Bringing our children up in a setting like this will reduce their chances for success while squandering their wealth on things they can do without."

The remaining participants ( 3 students) argue that human poverty is linked to one's predetermined luck. More so, being born into a particular family might make him a prince or a pauper since human wealth or poverty is beyond one's control. Notably, the focus group's results documented a poor understanding of fatalism for those who reiterated it. They completely discarded the individual's necessary effort and skills, which defy the core definition where one must do things to his greatest effort, then leave the rest to God's fate. 
Table (4) means and standard deviations of the dependent variables (N=762)

\begin{tabular}{|c|c|c|c|}
\hline Factor & Item & Mean & $\begin{array}{c}\text { Std. } \\
\text { Deviation }\end{array}$ \\
\hline $\begin{array}{l}\text { Wealth Individualistic } \\
\text { List of Items }\end{array}$ & $\begin{array}{c}\text { Are hard working } \\
\text { Possess drive and perseverance } \\
\text { Live in strong families } \\
\text { Have high moral standards } \\
\text { Are thrifty } \\
\text { Are willing to take risks }\end{array}$ & $\begin{array}{l}2.312 \\
2.300 \\
2.298 \\
2.141 \\
2.100 \\
2.100\end{array}$ & $\begin{array}{l}.470 \\
.543 \\
.650 \\
.695 \\
.580 \\
.550\end{array}$ \\
\hline Average & & 2.208 & .581 \\
\hline $\begin{array}{c}\text { Wealth Structuralist } \\
\text { Items }\end{array}$ & $\begin{array}{c}\text { Have" Contact" and" Pull" } \\
\text { Have good education } \\
\text { Receive favoritism in hiring } \\
\text { Are shown favoritism in promotion and } \\
\text { wages } \\
\text { Receive large inheritances } \\
\text { Receive special treatment from } \\
\text { government }\end{array}$ & $\begin{array}{l}2.786 \\
2.635 \\
2.555 \\
2.500 \\
2.490 \\
2.400\end{array}$ & $\begin{array}{l}.564 \\
.669 \\
.690 \\
.789 \\
.713 \\
.747\end{array}$ \\
\hline Average & & 2.561 & .563 \\
\hline Wealth Fatalistic Items & $\begin{array}{c}\text { Good luck } \\
\text { Are born in well-known tribes } \\
\text { Higher intelligence }\end{array}$ & $\begin{array}{l}1.955 \\
1.900 \\
1.756\end{array}$ & $\begin{array}{l}.585 \\
.799 \\
.632\end{array}$ \\
\hline Average & & 1.870 & .672 \\
\hline $\begin{array}{l}\text { Poverty Individualistic } \\
\text { Items }\end{array}$ & $\begin{array}{c}\text { Lack suitable financial administration } \\
\text { Are unwilling to take risks } \\
\text { Abuse drugs and alcohol } \\
\text { Lack drive and perseverance } \\
\text { Are not thrifty } \\
\text { Are lazy }\end{array}$ & $\begin{array}{l}2.200 \\
2.177 \\
2.148 \\
2.106 \\
2.031 \\
1.569\end{array}$ & $\begin{array}{l}.701 \\
.755 \\
.624 \\
.820 \\
.698 \\
.763 \\
\end{array}$ \\
\hline Average & & 2.038 & .726 \\
\hline $\begin{array}{c}\text { Poverty Structuralist } \\
\text { Items }\end{array}$ & $\begin{array}{c}\text { Lack of social justice in society } \\
\text { Low level of education } \\
\text { Lack suitable employment } \\
\text { opportunities } \\
\text { Do not have "contacts" or "pull" } \\
\text { Dependency on government assistance } \\
\text { Low wages in some occupations } \\
\text { Study in public school }\end{array}$ & $\begin{array}{l}2.886 \\
2.755 \\
2.750 \\
2.660 \\
2.587 \\
2.500 \\
2.495\end{array}$ & $\begin{array}{l}.767 \\
.700 \\
.665 \\
.597 \\
.575 \\
.796\end{array}$ \\
\hline Average & & 2.661 & .657 \\
\hline Poverty Fatalistic Items & $\begin{array}{l}\text { Are born with low intelligence } \\
\text { Lack the talent to succeed } \\
\text { Chronic diseases and disabilities }\end{array}$ & $\begin{array}{c}1.655 \\
1.60 \\
1.430\end{array}$ & $\begin{array}{l}.718 \\
.702 \\
.702\end{array}$ \\
\hline
\end{tabular}




\begin{tabular}{|l|l|l|} 
Average & 1.521 & .719 \\
\hline
\end{tabular}

In short, the results of this study regarding beliefs of UAE university students about the causes behind wealth are not consistent with the findings of some studies in the United States (Hunt, 2004; Smith and Stone, 1989) where American respondents generally weigh the importance of individualistic explanations of wealth over other interpretations. Meanwhile, the results of this study are consistent with the findings of some studies in Russia (Gorshkov and Tikhonova, 2006). Moreover, while the focus of global studies revolved around poverty more than they did about wealth, a distinct lack of research on beliefs about wealth in the Arab world prevails; which reduces the possibility of comparing the results of this study to global studies.

The results of this study regarding university students' beliefs about causes of poverty are consistent with the results of some studies in Turkey (Morcol, 1997), Jordan (Alothman, 2010), and other European welfare states (Oorschot and Halman, 2000) where university students in U.A.E. believe in the importance of structuralist explanations of poverty. Further, the findings of the study contradict with other empirical literature in U.S.A. (Feagin, 1975; Huber \& Form, 1973; Kluegel \& Smith, 1985; Hunt, 1996; Smith \& Stone, 1989; Kluegel \& Smith, 1981; Hunt, 2004), where Americans generally give more weight to the individualisticexplanation causes of poverty. That is, the beliefs of research respondents in U.A.E. are more similar to the beliefs of respondents in some developing countries (Egypt, Turkey, Palestine and Jordan) and European welfare states in explaining poverty and thus differ from other developed countries. This might be attributed to the patriarchal ideology, as well as the role of the state in the socioeconomic development especially in improving social, educational, health, and economic life chances for its people. Thus, the state in U.A.E. has become the biggest owner of the resources. In addition, 
United Arab Emirates is regarded as a rentier state that depends on rentier oil. Dominant relations are based on distributing and recycling oil revenues which coexist with non-economic relations (tribal), and economic and financial dominance is exerted by category or class-monopolizing privileges (financial and commercial oligarchy). The majority of Emirati citizens lives relatively well-off and receives free health care, education, water, electricity. More so, welfare protection of vulnerable groups is effective, hence reinforcing the ideology of dependency on the government. Additionally, the modernization process in the U.A.E. over the last four decades has created more life opportunities and chances for both the local and non-local population to be positioned within the economic system (income, assets, and material resources) through people's motivation and hard work, and the ability to access power through kinship and tribal relationships in the country. Finally, the high and oftentimes incredible salaries for high-ranking positions cling in the army, national security department, and business sectors. This system is regarded as a form of redistribution policy for the elite in the country which automatically creates a wealthy class formed by the state. Relatively, this policy also created a poor segment of the population through a large gap between some citizens' personal income.

The core question is who to blame: individual, society, or fate when explaining causes of wealth and poverty in UAE. Pearson correlation coefficients ( $r$ ) were used to answer this question. According to table 5, respondents who live in region 1 (Abu Dahbi, Dubai, and Sharjah) are more likely than their counterparts living in region 2 (Ajman, Ras al-Khaimah, Fujairah, and Umm al-Quwain) to support individualistic explanations of wealth. On the contrary, respondents who live in region 2 are more likely to embrace structuralist explanations of wealth than their counterparts who live 
in region 1. However, region remained a silent variable in affecting beliefs toward causes of poverty or fatalistic explanation of wealth. In other words, the respondents hold similar beliefs about fatalistic explanations of poverty and wealth regardless of their region. The focus group discussion results revealed that respondents from region 2 were less supportive toward individualistic explanations of wealth, and more toward the structuralist explanations compared to their region 1 counterparts. The difference between the respondents' beliefs about wealth may be linked to the level of modernization and development which entailed more life opportunities in the richer Emirates (region 1) compared to the poorer four Emirates (region 2). More so, region 2 is more dependent on the federal government of UAE than region 1 .

Additionally, age was found to be positively correlated with respondents' beliefs toward causes of individualistic explanation of wealth, and negatively correlated with respondents' beliefs toward structural explanation of wealth. The focus group discussions support the result of this quantitative analysis. This correlation may be attributed to the differences in life experience and social and economic circumstances. Also, no significant correlation was found between age and all dimensions of poverty explanations and fatalistic explanations of wealth. 
Table (5) Values of Pearson r correlation between independent variables and dimensions of beliefs toward causes of wealth and poverty

\begin{tabular}{|c|c|c|c|c|c|c|}
\hline \multirow{2}{*}{$\begin{array}{c}\text { Socio- } \\
\text { demographic } \\
\text { variables }\end{array}$} & \multicolumn{5}{|c|}{ Dimensions of Beliefs toward Causes of Wealth and Poverty } \\
\cline { 2 - 7 } & $\begin{array}{c}\text { Wealth- } \\
\text { Individualism }\end{array}$ & $\begin{array}{c}\text { Wealth- } \\
\text { Structuralism }\end{array}$ & $\begin{array}{c}\text { Wealth- } \\
\text { Fatalism }\end{array}$ & $\begin{array}{c}\text { Poverty - } \\
\text { Individualism }\end{array}$ & $\begin{array}{c}\text { Poverty - } \\
\text { Structuralism }\end{array}$ & $\begin{array}{c}\text { Poverty- } \\
\text { Fatalism }\end{array}$ \\
\hline Region & $.177^{*}$ & $-.189 *$ & .005 & .016 & .011 & .040 \\
\hline Age & $.225^{*}$ & $-.128^{*}$ & .009 & .052 & .049 & .036 \\
\hline $\begin{array}{c}\text { Family } \\
\text { Income }\end{array}$ & .015 & .052 & 019 & $.302^{*}$ & $-.299 *$ & -.047 \\
\hline Sex & .059 & -.060 & -.011 & $.332^{* *}$ & $-.278^{* *}$ & $-.230^{*}$ \\
\hline $\begin{array}{c}\text { Subjective } \\
\text { Social Class }\end{array}$ & -.002 & .029 & -.024 & $-.299 *$ & $-.319 *$ & .031 \\
\hline $\begin{array}{c}\text { Nationality } \\
\text { Religiosity }\end{array}$ &. $.109 *$ & .064 & .064 & .018 & $.103 * *$ & .002 \\
\hline
\end{tabular}

*Correlation is significant at the 0.05 level (2-tailed).

** Correlation is significant at the 0.01 level (2-tailed).

Social status (family income and subjective social class) was found to be negatively correlated with respondents' beliefs about causes of structural explanations of poverty, and positively correlated with individualistic explanations of poverty. This might be explained by the importance of social class or statuses that may predict life attitudes and beliefs. People with lower status are more in need for the intervention of the state to help them, and more affected by the structural forces in the country, and have limited chances available for them compared to high-status people. Also, people with higher status perceived wealth as a product of their exceptional effort which reflects their self-interest in the inequality system. No 
correlation was found between social status and wealth explanations.

Sex was found an inconsistent variable in the previous empirical literature in explaining beliefs about causes of poverty. However, in this study, sex was documented as a silent variable in explaining wealth, while females were more supportive toward structuralist and fatalistic explanations of beliefs about causes of poverty than males. The focus group discussion supported the same abovementioned notion. This empirical result may be due to the structural forces in the U.A.E. and the Arab world where the dominant ideology is that of patriarchy which gives power to men rather than women. Further, women as a social category are more in need of state intervention to assist them, are more affected by the structural forces, and have limited chances available for them compared to men.

Nationality was correlated with youth's beliefs about individualistic explanations of wealth and structural explanations of poverty. In other words, Emirati youth are less likely than non-Emiratis to attribute wealth to individualistic explanation, and more likely than non-Emiratis to attribute poverty to structural explanation. The focus group results agree with the social survey regarding nationality. The difference could be explained by the social and political reality that the Emirati citizens enjoy more privileges compared to non-emaratis in their wages, promotions, government support and preferences. For instance, an Emirati would expect his government to pay back his debt when he or she has trouble paying it off, and cling on to high ranking positions.

Religiosity was found only to be positively correlated with individualistic explanations of wealth. No correlation was found between religiosity and other scales explaining wealth and poverty. This correlation could be explained by the effect of religiosity on the 
personal discipline of individuals, their hard work, and their honesty.

\section{Conclusion}

In this study, quantitative and qualitative analysis results revealed that the student participants carry beliefs about wealth and poverty caused by structural and societal factors in the first place, and individualistic factors in the second. However, fatalistic factors were represented minimally in the participants' beliefs. These beliefs reflect the State's historical and realistic role in UAE society. Emirati society is undergoing a transitional phase that combines properties of both traditional societies and modern ones.

The modernization Emirati society underwent relied heavily on the state, which in their turn made it possible by investing oil revenues in order to establish modern cities and build educational, health, and housing systems. Thus, the relationship between state and society remains a parental relationship (patriarch) based on loyalty to the ruler or chief of tribe. Therefore, rulers of the Emirates distribute scarce resources (money, land, homes, or even important functions) to the parish, and ensure loyalty to them in return. While it may be desirable for the state to play the leading role in the modernization and development process during the early stages of establishing a developing country, the continuation of this role will reflect negatively on the beliefs and perceptions of individuals towards issues of social inequality.

Therefore, the beliefs, especially those revolving around the social inequality system, are determined by the individual's status within this system and directly relevant to one's expertise and personal benefits. Notably, the larger percentage of participants' beliefs contradict with the UAE's new developmental visions and policies which shift the role of the state and instead foster growth and 
individual initiative, as well as advocate the private sector to take its role in leading the economy and become a substitute for the public sector. All of this requires promoting individual initiative and achievement values, and self-reliance and creativity among individuals by setting up achievable and long term goals across the seven emirates and embedding them in school and university curricula in conjunction with primary and official institutions.

Emphasizing the importance of the individual decision-making is vital when re-examining UAE developmental policies. It is pivotal to the future challenges that the country will face with the depletion in oil prices and the eventual dry up of oil reserve in the near future. A change in the dominant ideology in the UAE - which is based on the individual's dependence on the state-, will change the individuals' beliefs to factor both individualist and structuralist explanations rather than beliefs that perpetuate state-dependence. Moreover, misunderstanding fate and destiny may be resolved, which at its core relies on hard work and taking the means to achieve targets at both individual and community levels. To conclude, organizing a social environment that is based on competition between individuals according to their merits and abilities rather than traditional values associated with the tribe and kinship; will accelerate the transformation of individual perceptions toward a system of social justice, and intensify the pace of modernization and development in the long run. 


\section{$\underline{\text { References }}$}

1) Abouchedid, $K$ and Nasser, $R$ (2001) Poverty Attitudes and their Determinants in Lebanon's Plural Society. Journal of Economic Psychology, 22: 271 - 282.

2) Asiedu, C., Dzukoto, V., Wallace, D., Mensah, E.,(2013). Conceptions of Poverty and Wealth in Ghana, International Journal of Business and Social Science,4(9),18-28.

3) El laithy, H.( 1997). Structural Adjustment and Poverty, in Alia Elmahdi (ed), Aspects of Structural Adjustment in Africa and Egypt, Cairo university Center for Developing Counties Studies.

4) Alothman, H (2005) Jordanian Beliefs in Al-Karak Governorate about the Causes and Determinants of Poverty: Field Study. Journal of Development and Economic Policies, 7 (2): 7 - 36.

5) Arab League (2013) Joint Arab Economic Report. Abu Dhabi: Arab Monetary Fund.

6) Cozzarelli, C Wilkinson, A and Tagler, M (2001) Attitudes Toward the Poor and Attributions. Journal of Social Issues 57: 207 $-227$.

7) Feagin, J (1972) We Still Believe that God Helps those Who Help themselves. Psychology Today, Volume 6: $101-29$.

8) Feagin, J (1975) Subordinating Poor Persons: Welfare and American Beliefs: Englewood Cliffs, NJ: Prentice-Hall.

9) Feather, N (1974) Explanations for Poverty in Australian and American Samples: The Person, Society, and Fate. Australian Journal of Psychology 26: 199 - 216.

10) Furnham, A (1982) Why the Poor Always With Us? Explanations for Poverty in Britain. British Journal of Social Psychology 21: $311-322$.

11) Gorshkov, $M$ and Tickhnova, $N$ (2006) Wealth and Poverty in the Perceptions of Russians. Sociological Research, 45: 27 - 40. 
12) Hadj, G. (2014). The Phenomenon of Poverty in Alegria And Its Effects on The Social Fabric In The Light of Financial Boom, Unemployment and Inflation, The Academy For Social And Human Studies, 12, 16-25.

13) Hasan, A. (2005) Poverty in Palestine and its Policy Resisting Study case (Jenin Governorate), M A Not Published Thesis AnNajah National University.

14) Hine D and Montiel C (1999) Poverty in Developing Nations: A Cross-Cultural Attributional analysis. European Journal of social Psychology 29: 943 - 959.

15) Huber, J and Form, W (1973) Income and Ideology. Free press: New York.

16) Hunt, M (2002) Religion, Race/ethnicity, and Beliefs about Poverty. Social Science Quarterly, 83: 810 - 831.

17) Hunt, M (2004) Race/ethnicity and Beliefs about Wealth and Poverty. Social Science Quarterly, 85: 827 - 853.

18) Hunt, M (1996) The Individual, Society, Or both? A Comparison of Black, Latino, and White beliefs about the Causes of Poverty. Social Forces, 75: 293 - 322.

19) Al Kahtani, M. (2004). The Problem of Poverty In Saudi Society: A Field Study In Al Riyadh, M A Not Published Thesis, The University of Jordan.

20) Kluegel, J and Smith, E (1986) Beliefs about Inequality: American Views of What is and What Ought to be. New York: Aldine De Gruyter.

21) Kreidle, M (2000) Perceptions of Poverty and Wealth in Western and Post-Commubist countries. Social Justice Research, 13: 151 176.

22) Medeiros, $M$ and Ferreiros de Souza, P. 2015. The Rich, the Affluent and the Top Incomes. Current Sociology, 63: 869 - 895.

23) Mervat, S. (2016). Living Adaptation Methods For House Hold Woman In The Light of Feminization Poverty In Some Egyptian 
Governorates, Agricultural Extension And Rural Development Research Center, ARC, GIZA, Egypt.

24) Moghadam, V ( 2013) What is Democracy? Promises and Perils of the Arab Spring. Current sociology, 61(4), 393 - 408.

25) Morcol G (1997) lay explanation for poverty in Turkey and their determinants. The Journal of social Psychology, 137: 728 - 738.

26) Niemela M (2008) Perceptions of the causes of poverty in Finland. Acta Sociolgica 51: 23 - 40.

27) Nasser, R; Abouchedid, K and Khashan, H (2002) Perception of the Causes of Poverty Comparing three National Groups: Lebanon, Portugal, and South Africa. Current Research in Social Psychology, 8: 1 - 14.

28) National Bureau of Statistics. 2009. Household Income and Expenditure Survey. Abu Dhabi.

29) Oorshot, W and Halman, L (2000) Blame of Fate, Individual or Social? An International Comparison of Popular Explanations of Poverty. European Societies 2(1): 1 - 28.

30) Robinson, J (2009) American Poverty Cause beliefs and Structured Inequality legitimation. Sociological Spectrum 29: 489 $-518$.

31) Rothman, R (2004) Inequality and Stratification: race, Class and Gender. Routledge.

32) Salih, K ( 2013) The Roots and Causes of the 2011 Arab Uprisings. Arab Studies Quarterly, 35 (2): 184 - 206.

33) Shahateet, M (2007) The Determinants of Deprivation in Jordan: Empirical Study, Journal of Social Sciences, 3(1).

34) Sheck, D and Man-SzeMa, C (2008) Dimensionality of the Chinese Perceived Causes of Poverty Scale: Findings Based on Confirmatory Factor Analyses. Social Indicator Research 90: 155 164. 
35) Sheck, D (2003) Chinese People's Explanations of Poverty: The Perceived Causes of Poverty Scale. Research on Social work Practice 13: 622 - 640.

36) Smith, K and Stone, L (1989) Rags, riches, and Bootstraps: Beliefs about Causes of Wealth and Poverty. The Sociological Quarterly 30: 93 - 107.

37) Smith, K (1985) I Made it Because of Me: Beliefs about the Causes of Wealth and Poverty. Sociological Spectrum 5: 255 267.

38) Stephenson, S (2000) Public Beliefs in the Causes of Wealth and Poverty and legitimization of inequalities in Russia and Estonia. Social Justice Research, 13(2): 83-100.

39) United Nations Development Program (UNDP) (2014) Human Development Report 2014. New York: USA. 